\title{
DETERMINATION OF THE VOCATIONAL TAXONOMY HIERARCHY FOR HIGHER VOCATIONAL SCHOOL
}

\author{
Sadrina $^{1^{*}}$, Norhazizi Bin Lebai Long ${ }^{2}$, Ramlee Mustapha ${ }^{3}$, Yuyun Yuana ${ }^{4}$ \\ ${ }^{1}$ Department of Electrical Engineering Education, Faculty of Tarbiyah and Teaching, \\ Universitas Islam Negeri Ar-Raniry Banda Aceh \\ Jl. Syeikh Abdul Rauf Street Banda Aceh, Aceh, Indonesia. 23111 \\ *Email:sadrina@ar-raniry.ac.id \\ ${ }^{2}$ Kolej Vokasional Malaysia \\ ${ }^{3}$ Department of Technical and Vocational Education, Faculty of Technical and Vocational Education, Sultan Idris \\ Education University \\ Perak, Tanjong Malim, Malaysia. 35900 \\ Email: drramlee@yahoo.com \\ ${ }^{4}$ SMK Negeri 1 Jeunib \\ Banda Aceh-Medan Street Bireun, Aceh, Indonesia. 24263
}

\begin{abstract}
Taxonomy can be defined as the naming or classification of an idea or name, according to one discipline. There is a lack of regulation in the concept of vocational education. Vocational education (SMK) cannot fully use Bloom's Taxonomy. Vocational Taxonomy is centered on psychomotor theory which emphasizes aspects of physical movement. However, the purpose of this research is to determine the appropriate Vocational Taxonomy hierarchical structure for SMKN 1 Jeunib. The design of this research is qualitative research which using interview method to assess the perception of the Vocational teacher in terms of determination the Vocational Taxonomy. The sample chosen was SMKN 1 Jeunib, Bireun, Aceh, which selected 54 teachers from all departments. The result presented that the teachers believed Vocational Taxonomy is important for SMK learning and teaching. In addition, the taxonomic function is very important and assisting in teaching and learning, aiding the curriculum preparation and contributing the practical activities. Then also, the taxonomy function is important in measurement and assessment of psychomotor activities. So, the Taxonomy was recommended to related parties (SMK, Polytechnic, Vocational College, or training Institution). The research also stated that there was a need for a link between cognitive and psychomotor aspects. Finally, the students not only mastered the aspects of knowledge but also proficiency.
\end{abstract}

Keywords: hierarchy, taxonomy, vocational

\begin{abstract}
Abstrak: Taksonomi dapat didefinisikan sebagai penamaan atau klasifikasi suatu gagasan atau nama, menurut salah satu disiplin ilmu. Regulasi dalam konsep pendidikan vokasi sangat kurang. Pendidikan kejuruan (SMK) tidak dapat sepenuhnya menggunakan Taksonomi Bloom. Taksonomi Vokasi berpusat pada teori psikomotorik yang menekankan pada aspek gerak fisik. Namun, tujuan dari penelitian ini adalah untuk menentukan struktur hierarki Taksonomi Kejuruan yang sesuai untuk SMKN 1 Jeunib. Rancangan penelitian ini adalah penelitian kualitatif yang menggunakan metode wawancara untuk menilai persepsi guru SMK dalam hal penentuan Taksonomi SMK. Sampel yang dipilih adalah SMKN 1 Jeunib, Bireun, Aceh yang memilih 54 guru dari seluruh jurusan. Hasilnya menunjukkan bahwa para guru percaya, Taksonomi Kejuruan penting untuk pembelajaran dan pengajaran di SMK. Selain itu, fungsi taksonomi sangat penting dan membantu dalam proses belajar mengajar, membantu penyusunan kurikulum dan berkontribusi dalam kegiatan praktek. Selain itu, fungsi taksonomi penting dalam pengukuran dan penilaian aktivitas psikomotorik. Sehingga Taksonomi direkomendasikan kepada pihak terkait (SMK, Politeknik, SMK, atau Lembaga Diklat). Hasil penelitian juga menyatakan bahwa perlu adanya keterkaitan antara aspek kognitif dan psikomotorik. Sehingga siswa tidak hanya menguasai aspek pengetahuan tetapi juga kecakapan.
\end{abstract}

Kata Kunci: hierarki, kejuruan, taksonomi

\section{Introduction}

Facing the 21st century millennial era, the nation's generation must have the competencies needed such as communication, collaboration, creative thinking skills, technological skills, interpersonal skills, and problem solving skills. To advance the functions of educational institutions, in case of vocational education, the Government seeks to compile the curriculum that accordance with the educational goals and objectives. The vocational education curriculum must meet the demands of the users (industry or 
company). However, in terms of implementing the curriculum, the problems are encountered, both for teachers, students or the school management itself. In addition, vocational education problems are related to scientific issues that are closely related to the world of work and industry. These issues are summarized in a module or taxonomy that currently used by the global education world.

Taxonomy can be defined as the naming or classification of an idea or name, according to one discipline. Etymologically, the term taxonomy comes from the Greek language, namely taxon which means collection or unit and nomos which means laws or rules that function to place one business in a particular taxon (Partha \& Kholia, 2010). Taxonomy can be defined as the grouping of things based on a certain hierarchy (level) (Wikipedia.org, 2019) or which means systematic, arrangement and division (Enghoff, 2009). Bloom's Taxonomy is a taxonomy that is widely used in the world of education and learning. Basically, Bloom's taxonomy was published in the 1950s, in a meeting of the American Psychological Association by Benjamin Bloom. Bloom's Taxonomy covers three domains, namely the Cognitive Domain, the Affective Domain, and the Psychomotor Domain. However, according to Jackie Greatorex \& Irenka Suto (2016), there is no perfect taxonomy that is appropriate with education. Among many taxonomies, according to those who approach and overshadow complex domains are Marzano and Kendall's Taxonomy (2007) and Hutchins et al. (2013).

In its implementation, Bloom's taxonomy does not cover the vocational education discipline. There is a lack of regulation in the concept of vocational education. Bloom's Taxonomy places more emphasis on cognitive aspects. Vocational education (SMK) cannot fully use Bloom's Taxonomy. Vocational Taxonomy is centered on psychomotor theory which emphasizes aspects of physical movement. However, vocational education is not entirely on the physical aspect, it still requires cognitive aspects. Thus, it's important to build the Vocational Taxonomy which is prepared with combining the cognitive and psychomotor aspects. However, in its implementation, the percentage of cognitive aspects is greater than psychomotor. Thus, the graduates from vocational education do not master complex competencies because of demands for more theoretical mastery.

There needs to review the Vocational School curriculum by integrating academic science with vocational fields. Realizing that vocational education graduates will not only master technical skills but also other abilities such as literacy, creative thinking, critical thinking, and problem solving ability (Ramlee et al., 2003). Psychomotor is the basis of vocational education. SMK students have a learning style that focuses on what the teacher transforms rather than just reading or listening. Psychomotor can be defined as gross and fine motor skills that are interrelated with other technical abilities (Mimi et al., 2014). According to Reynolds (1965) in Norhazizi \& Ramlee (2019), mentions that psychomotor learning involves a lot of physical (motor) and mental (psycho) activities.

Psychomotor abilities are determined by the existence of habits or practice exercises routinely. This means that there is "learning by doing" activity which is a concept of Dewey's theory. The field of vocational education requires a learning concept "learning by doing" and a "experiential learning" concept that combines practice and experience. This activity is an important motor ability to be arranged in a taxonomy. So it is necessary to have in-depth research on a vocational taxonomy that is fulfill the vocational education needs. An important aspect in the formation of Vocational Taxonomy, is the number of learning styles of SMK students. According to Ramlee (2012), there are at least three learning styles for vocational education students, namely cognitive, affective and manipulative (the suitability of the body and brain in carrying out physical activities).

It be concluded that taxonomy is required a specific knowledge classification regarding vocational education. In Indonesia, the vocational education curriculum does not respond to the needs of the Industry and affects the quality of competence of students. The ILO (International Labor Organization, 2013) states that there needs to be a policy from the state to overcome the miss-match curriculum problem and correct the wrong one. However, the purpose of this research is to determine the appropriate Vocational Taxonomy hierarchical structure for SMK N 1 Jeunib. 


\section{Materials and Methods}

This study aims to find new knowledge of an emerging phenomenon. In particular, the design of this study is the determination of a new taxonomy that is systematic and precise. The design of this research is qualitative research which using interview method to assess the perception of the Vocational teacher in terms of determination the Vocational Taxonomy. The sample chosen involved one vocational school, namely SMKN 1 Jeunib, Bireun, Aceh. This School has A and B accreditation in several field of expertise. The areas of expertise include agribusiness, agricultural product processing, boutique clothing, fishery, automotive engineering, fishing vessel Nautica, fishing vessel engineering, and hospitality. With many achievements obtained, this school is considered sufficiently representative of SMK in Aceh. Respondents used were teachers of SMKN 1 Jeunib which selected 54 teachers from all departments.

In this study, the instrument selected was a set of open-question questionnaire to assess the teachers' perception of Vocational Taxonomy. There are five questions asked to them. This study conducted a validity test by involving one professor from Malaysia. In quantitative research, the main data collection technique is distributing open-question questionnaire to 54 teachers to obtain data about their perceptions of the vocational taxonomic domain. The results of the Cronbach alpha test with SPSS ver 20 , obtained a value of $\alpha=0.77$, which means that the items on this instrument are suitable for use.

\section{Result and Discussion}

The result presented the teachers' statement about the vocational taxonomy for the vocational school (SMK) in Aceh. From the Table 1, the teachers believed that Vocational Taxonomy is important for SMK learning and teaching (item 1).

Table 1. Teachers' agreement of vocational taxonomy

\begin{tabular}{lc}
\hline & Item \\
\hline 1. Do you agree that Vocational Taxonomy is important for the SMK teachers? \\
a. Yes & $54(100 \%)$ \\
b. No & - \\
\hline
\end{tabular}

Furthermore, the teachers were asked to state the level of importance of the taxonomic function in vocational education. In Table 2 , the taxonomic function is very important and assisting in teaching and learning, aiding the curriculum preparation and contributing the practical activities. In addition, the taxonomy function is important in measurement and assessment. However, one teacher of the SMKN 1 Jeunib stated that taxonomy is not important for its function in learning and teaching, curriculum preparation, practical activities and measurement and assessment. Generally, it can be concluded that taxonomy plays an important role in the successful of the teaching and learning process of SMKN 1 Jeunib. Finally, it is necessary to revise on the correct and precise of the taxonomic arrangement.

Table 2. Analysis of taxonomic importance in vocational school education

\begin{tabular}{|c|c|c|c|c|}
\hline Item & $\begin{array}{c}\text { Very } \\
\text { Important }\end{array}$ & Important & $\begin{array}{c}\text { Less } \\
\text { Important }\end{array}$ & $\begin{array}{c}\text { Not } \\
\text { Important }\end{array}$ \\
\hline \multicolumn{5}{|c|}{$\begin{array}{l}\text { 2. If you agree that vocational taxonomy is important, } \\
\text { please choose its importance according to the taxonomic } \\
\text { function in vocational education. }\end{array}$} \\
\hline a. Teaching and learning & 33 & 17 & - & 1 \\
\hline b. Curriculum Development & 29 & 22 & - & 1 \\
\hline c. Practice Activities & 29 & 21 & - & 1 \\
\hline d. Measurement and Assessment & 21 & 27 & - & 1 \\
\hline
\end{tabular}

Furthermore, teachers are asked their agreement in terms of the vocational taxonomy that has been compiled by the taxonomist. The suggestions of taxonomists are as follows: 


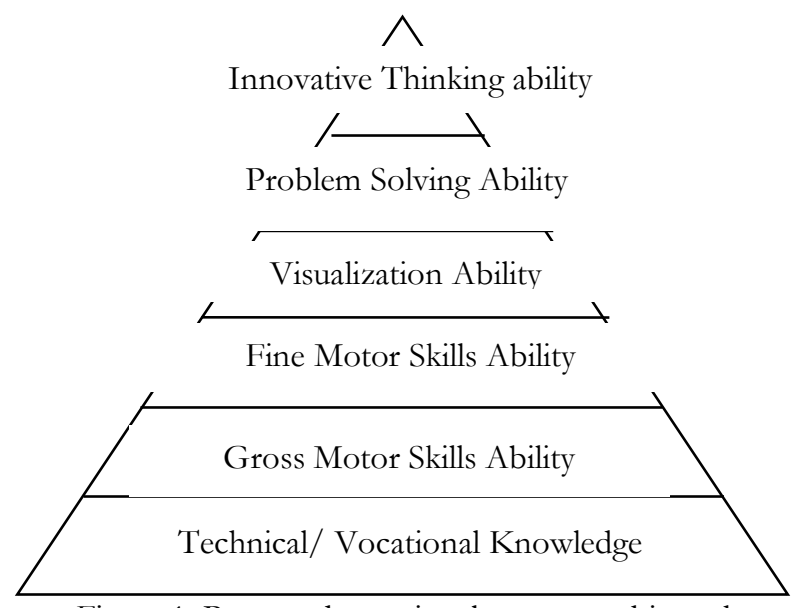

Figure 1. Proposed vocational taxonomy hierarchy

Further, the teachers were requested to give their agreement of the proposed Vocational Taxonomy by the taxonomist. From the Table 3, presented the teachers perception of those hierarchy. There are $98 \%$ of teachers agreed with the taxonomic hierarchy proposal designed by taxonomists. Meanwhile, one teacher $(2 \%)$ disagreed and made the proposed taxonomy according to personal knowledge.

Table 3. Teacher approval of the taxonomic hierarchy

\begin{tabular}{cc}
\hline \multicolumn{1}{c}{ Item } & Frekuensi (\%) \\
\hline 3. Do you agree with the order of the taxonomic hierarchy? & $53(98 \%)$ \\
a. Yes & $1(2 \%)$ \\
b. No & $1 \%$ \\
\hline
\end{tabular}

The suggestions of teacher who refused the form of the vocational taxonomic hierarchy above is as follows. Figure 2, showed a proposed taxonomic hierarchy based on the opinion of Mr. X as the Jeunib $1 \mathrm{SMKN}$ teacher. At the basic level is intended for the aspect of Rough Motor Ability, followed by the Fine Motor Ability in the second level. At the third and fourth are positioned for domain of technical knowledge and visualization skills. While the fifth and sixth level, was ordered to domain of the Ability to Solve Problems and the Ability to Think Innovation. These stage was similar as the order proposed by taxonomists.

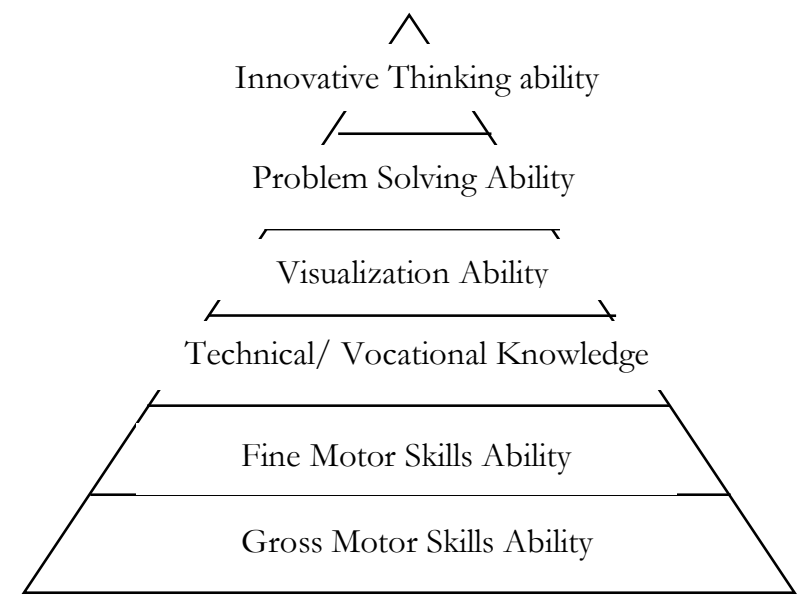

Figure 2. Mr. Teacher's proposed vocational taxonomy hierarchy

The last item from the open questions questionnaire were suggestions and recommendations from the SMKN 1 Jeunib's teachers about the Vocational Taxonomy. The numbering of suggestions and recommendations followed the teacher's majority answers. 
Table 4. Teachers' Suggestions and Recommendations on the Taxonomic Hierarchy

\begin{tabular}{cl} 
No & Suggestion \\
\hline 1. This vocational taxonomy is acceptable to be implemented in SMK, but its development needs to follow-up. \\
2. Hopefully, the application of vocational taxonomy in SMK can help entrepreneurship-based learning \\
3. This Vocational Taxonomy needs alignment in the application of the curriculum. Thus, it would achieved the aim \\
of thinking and practicum ability. \\
5. Improve motivation in learning and vocational taxonomy learning model. \\
6. The vocational taxonomy will provide benefits for vocational teachers. Further, it would create a comprehensive \\
7. The Vocational taxonomy is important for learning in SMK because it deals with cognitive, technique, theory and \\
practice in the laboratory \\
ability to think and practice which corresponds for the business and industrial world.
\end{tabular}

\section{Recommendation}

1. In terms of Vocational knowledge application, the practice learning is higher $(60 \%)$ than theory learning (40\%). It might affect the taxonomy level. Hopefully, there will be a further research related about this.

2. The vocational taxonomy is important in vocational schools. It would increase the balance of thinking and practicum that needed in the 21 st century skills.

3. Vocational taxonomy is appropriate for compiling the SMK curriculum

4. It is necessary to continue the similar research by increasing the number of sampling school for the research that would represented the result.

5. It is important to socialize about vocational taxonomy for vocational teachers as the main subject in the learningteaching process.

Based on the data from the interviewee in open question, it can concluded that the appropriate vocational taxonomy hierarchical arrangement for SMKN 1 Jeunib as preview below (Figure 3). In general, the teachers of SMKN 1 Jeunib agreed with the proposed hierarchy of vocational taxonomy suggested by taxonomists. It can believed that the most basic level is Technical Knowledge, the second level is Gross Motor Ability, the third is Fine Motor Ability, the fourth is Visualization Ability, the fifth is the Ability to Solve Problems and the last is the Thinking Innovation Ability. It would benefit to facilitate the learning-teaching process, compile the vocational curriculum, guide the practicum activities and assist the assessment and measurement process.

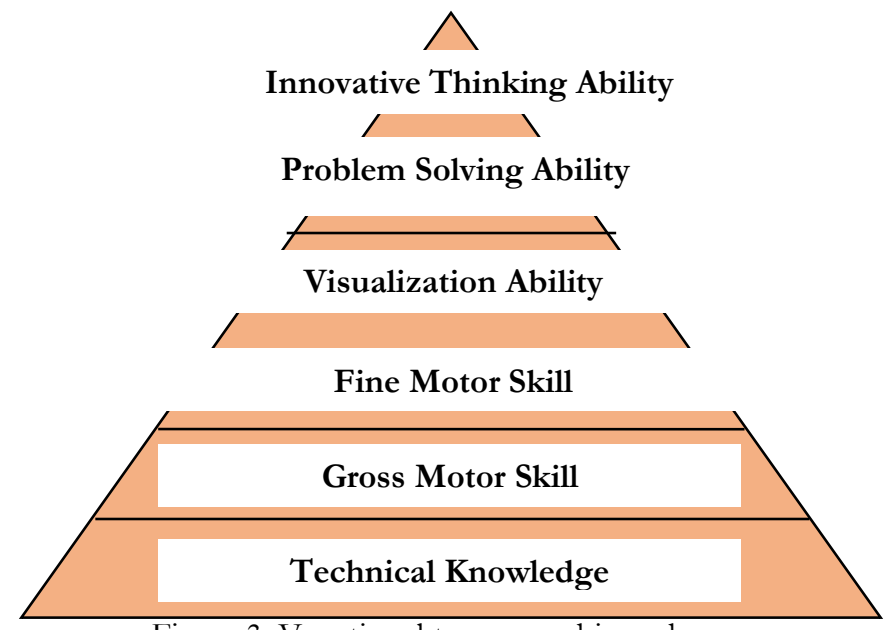

Figure 3. Vocational taxonomy hierarchy

The results indicated that the respondents were strongly agreed with the determination of the proposed Taxonomy domain. The results of the empirical data presented that the function of Vocational Taxonomy is very important for teaching and learning of SMK, necessary for curriculum preparation, and significant in terms of practical activities. Vocational taxonomy is also considered important for aspects of measurement and assessment. Teaching and learning aspects are very important in vocational 
education in SMK. Based on the research data, the respondents suggested that innovative, creative and active learning was significant need. Thus, the appropriate learning methods for vocational education include demonstrations, simulations and project-based learning (Norhazizi \& Ramlee, 2019).

Based on the teachers' perception, the gross motor skills, fine motor skills and visualization abilities are appropriate to the interests of learning and teaching. While, this ability correspond to the principles of Simulation and Demonstration Learning Models. Then, the PBL model is intended to the problem solving ability and innovative thinking domain. In terms of the curriculum development, practical or hands-on activities are important to develop their knowledge in psychomotor skills (Abigail, 2016). The taxonomy domains that appropriate with this importance are Fine Motor Abilities and Gross Motor Skills. According to Norhazizi \& Ramlee (2019), to improve their practical ability, students need to remediate their psychomotor competence. According to respondents, Vocational Taxonomy is important in practical activities that involve gross motor skills and fine motor skills.

For the purposes of measurement and assessment, vocational taxonomy is important. There are at least three educational assessment functions related to the vocational education, namely (i) improving the quality of vocational learning and teaching, (ii) determining the competence of education participants and (iii) determining the success of a program (US Congress, Office of Technology Assessment, 1992). The context of Vocational Taxonomy which aims to measure and assess technical knowledge are gross motor and fine motor skills domain. The assessment of practicum activities included measurement of speed, accuracy and implementation steps. Meanwhile, the visualization stage of the assessment involved graphic communication skills which related to the design ability. Finally, the assessment at the problem-solving and innovation aspects are the ability to generate and realize new ideas (Norhazizi \& Ramlee, 2019).

Basically, the Vocational Taxonomy is a taxonomy in the form of a hierarchy, which means that learning at the top level depends on the knowledge and abilities in the lower step before. Thus, the taxonomy structure in the form of a hierarchy, made the teachers understand the level of ability that students must learn from the low to the high level.

\section{Conclusion}

The results of this study are a Vocational Taxonomy which important in the teaching and learning process of SMK, curriculum preparation, practical activities and assessment and measurement processing. The Taxonomy is organized according to Simpson, Harrow and Dave's psychomotor theory. Based on the research data, it is concluded that the Vocational Taxonomy is built with six domains, namely (1) domain of technical knowledge, (2) domain of gross motor skills, (3) domain of fine motor skills, (4) domain of visualization, (5) domain of problem solving and (6) innovative thinking domain.

Based on the results, the teachers of SMKN 1 Jeunib strongly agreed with the preparation of Vocational Taxonomy. So, the Taxonomy was recommended to related parties (SMK, Polytechnic, Vocational College, or training Institution). The teachers also stated that there was a need for a link between cognitive and psychomotor aspects. Finally, the students not only mastered the aspects of knowledge but also proficiency.

\section{Acknowledgements}

Authors thank LP2M, Universitas Islam Negeri Ar-Raniry Banda Aceh for the opportunity given to the authors to conduct a research as well as the grants given for the research.

\section{References}

Abigail, J. O. 2016. Enhancing psychomotor skill acquisition in vocational education: strategy for bridging gap between teaching and research. Multidisciplinary Journal of Research Development 25(1): 1-6.

Enghoff, H. 2009. What is taxonomy? An Overview with Myriapodological Examples. Soil Organisms 81(3): 441-451.

Greatorex, J., \& I. Suto.2016. Extending Educational Taxonomies from General to Applied Education: Can They Be Used to Write and Review Assessment Criteria?. Conference on EARLI SIG I "Assessment and Evaluation": 1-4.

Hedden, H. 2014. Opportunities in freelance taxonomy work. Key Words 22(12): 165-167.

Iddekinge, C., Putka, D., Roth, P., \& Lanivich, S. 2011. Are you interested? A Meta analysis of relations between vocational interest and employee performance and turnover. Journal of Applied Psychology 96(6): 167-1194.

International Labour Organization (ILO). 2013. Global Employment Trends 2013. Switzerland: ILO. 
Marzano, R., \& Kendall, J. 2007. The new taxonomy of educational objectives (2nd Ed.). Thousand Oaks, CA: Corwin Press.

Mustapha, R. 2012. Prinsip kepada pendidikan teknikal \& vokasional. Tanjong Malim: Fakulti Pendidikan Teknikal \& Vokasional, Sultan Idris Education University.

Mustapha, R., \& A. Abdullah. 2002. School-to-work and vocational training in Malaysia. International Journal of Vocational Education and Training 8: 69-88.

Mustapha, R., R.M. Yasin., \& H.M. Ali. (2003). Integrasi akademik \& vokasional: Rasional \& cabaran. Jurnal Pendidikan 28: $77-$ 90.

Norhazizi, L.L., \& Mustapha, R. 2019. Analisis taksonomi bloom dalam penilaian vokasional: pembangunan suatu taksonomi baharu menggunakan teknik Delphi. Journal of Quality Measurement and Analysis JQMA 15(1). 65-75

Partha \& Kholia. (2010). Indian integrated plant taxonomic information system: A conceptual framework. DESIDOC Journal of Library \& Information Technology, 30(3), 35-42.

Polya, G. 1985. How to Solve It. New Jersey: Princeton University Press.

Website Wikipedia. https://id.wikipedia.org/wiki/Taksonomi (diakses pada Agustus, 2019).

Yagi, K., Bialek, H., Taylor, John E., \& Garman, M. 1971. The Design and Evaluation of Vocational Technical Education Curricula Through Functional Job Analysis. HumRRO Technical Report 71-15

Zorluoglu, Levent. S., Sahinturk, Ayse. \& Bagriyanik, Kubra. 2017. Analysis and evaluation of science course curriculum learning outcomes of the year 2013 according to the revised Bloom Taxonomy. Bartin University Journal of Faculty of Education 6(1): 1-15. 